Article

\title{
Reporting in Conflict Zones in Pakistan: Risks and Challenges for Fixers
}

\author{
Kiyya Baloch ${ }^{1, *}$ and Kenneth Andresen ${ }^{2}$ \\ ${ }^{1}$ NLA University College, 5812 Bergen, Norway; E-Mail: kiyya.baloch@gmail.com \\ 2 Institute of Media and Nordic Studies, University of Agder, 4630 Kristiansand, Norway; E-Mail: kenneth.andresen@uia.no \\ * Corresponding author
}

Submitted: 30 September 2019 | Accepted: 17 December 2019 | Published: 25 February 2020

\begin{abstract}
As a backbone of reporting in war and conflicts, fixers offer essential assistance to the foreign correspondent in conflict zones, also in Pakistan. With valuable local knowledge and contacts, fixers can arrange travel to secure entry of foreign correspondents into conflict zones in addition to securing interviews with otherwise unattainable figures, while offering reliable translation services. Pakistani media, despite being one of the largest and most developed in South Asia, remains under the strict control of powerful military establishment and government, while seeming to mirror the overarching government sentiment with a distinct lack of research-based news. Challenging this state of affairs, local journalist fixers seek to conduct research and investigative journalism, making them an attractive asset for western correspondents travelling to Pakistan. Based on data from interviews with local fixers and journalists in Pakistan, this article reveals the many security problems for local fixers in the Balochistan and Khyber Pakhtunkhwa regions in Pakistan. It also shows that the fixers' rights and interests are not protected by media organizations or the governments. Additionally, fixers face increasing censorship from security agencies and death threats from militants. This study discusses the harsh realities fixers face in the conflict zones of Pakistan where international press lack access due to increasing restrictions imposed by the government, and the violence perpetrated against media workers by the Islamic State and other radical groups, like Taliban and Baloch separatists.
\end{abstract}

\section{Keywords}

conflict zones; fixers; journalism; Pakistan; security

Issue

This article is part of the issue "Rethinking Safety of Journalists" edited by Kristin Skare Orgeret (Oslo Metropolitan University, Norway) and William Tayeebwa (University of Makerere, Uganda).

(C) 2020 by the authors; licensee Cogitatio (Lisbon, Portugal). This article is licensed under a Creative Commons Attribution 4.0 International License (CC BY).

\section{Introduction: The Need for Fixers in Pakistan}

When armed men stormed a five-star luxury hotel in Pakistan's restive Balochistan province in the southern port city of Gwadar in May 2019, the attack quickly triggered international media coverage. News organizations from across the globe, such as Xinhua News Agency, Al Jazeera, BBC, and CNN, provided media coverage from the impoverished coastal town in Pakistan's troubled southwestern province of Balochistan (BBC, 2019).

As audiences from across the world followed live coverage of the attack through videos, photographs, and soundbites, it was the local fixers who worked behind the scenes, risking their lives to provide live coverage of the attack for foreign correspondents stationed in Islamabad and New Delhi. Foreign correspondents were not granted free access to the conflict zone located in the Balochistan province, which borders with Iran. For such access, they would require a special permit called 'No Objection Certificate' (NOC) granted by the Ministry of Interior in Islamabad. These permits are rarely issued to foreign journalists, as such making them totally dependent on locally based media workers to cover this terror attack. Local fixers like Behram Baloch sourced valuable information from this remote corner of Pakistan. He alone coordinated information with more than a 
dozen foreign correspondents, spending his days meeting and interviewing top government officials, Chinese labourers working at the port, local people, and even the leaders of the separatist movement that took responsibility for the attack. If local journalists from larger cities of Pakistan like Lahore, Karachi, and Islamabad visited the city aftermath of the attack, they had to approach Bahram to arrange their meetings with government officials and local ethnic Baloch people. Those writing copy for international press agencies were standing tall on the shoulders of unknown giants like Behram Baloch.

Acknowledging such crucial importance to journalistic practice in Pakistan, this article examines the underlying challenges and risks fixers face. A fixer is a media practitioner who helps foreign reporters arrange interviews, while navigating and providing the broader context to the story at hand (Murrell, 2015; Palmer, 2019). The foreign correspondents we interviewed for this study defined fixers as "resourceful media workers." In the Pakistan context, Professor Altaf Khan describes fixers as "a reporter from within conflict zones who have the job of providing the raw material for stories to be published in Western media" (Khan, 2019). In Pakistan's southwestern Balochistan and northern Khyber Pakhtunkhwa (KPK) provinces, fixers work with the constant threat of violence from country's powerful military, drug mafia, Islamist extremist such as the Taliban, and ethnic Baloch separatists (Aslam, 2015).

Fixers in these provinces live in a high-risk environment. Pakistan's fixers face immense pressure and some of them even have lost their lives merely for contributing stories to international media (Khan, 2019). These bordering regions operate under media blackout where the local journalists, let alone foreigners, must show great caution while reporting. Normally, foreign journalists are not allowed to move outside of the capital city Islamabad without permission, and they are required to hold the NOC to travel to Pakistani conflict zones (Khan, 2019). Consequently, they rely on fixers to report stories. Fixers risk their safety contributing to international media by interviewing controversial Afghan and top Al-Qaeda militants for a "handsome amount" (Beck \& Delmenico, 2017).

To understand the dangers fixers encounter chasing stories for western media agencies in Pakistan's remote but troubled regions, we have framed the following research questions:

1) What risks do fixers face when working with foreign correspondents in Pakistan's troubled provinces?

2) How do local authorities and foreign correspondents treat their local counterparts?

3) How and why are fixers threatened during their work for the western media in Pakistan's volatile regions?

\section{Background and Literature: Journalists and Fixers Working in Pakistan's Troubled Areas}

\subsection{Theoretical Framework: Fixers, Journalism, and Professionalism}

An analysis of security issues for fixers in Pakistan can be theoretically grounded in a discussion of why fixers operate in dangerous areas, and how and why foreign reporters depend on them. In this regard, a discussion on framing the work of fixers is important. During the last few years, fixers have become the centre of attention in international journalism. In a special issue of Journalism Studies published in 2019, entitled "Reporting Global while Being Local: Local Sources of News for Distant Audiences," multiple studies investigated the interaction between international reporters and local 'helpers' or fixers. In one of the articles, Hoxha and Andresen (2019) map some of the research about the global importance of fixers. They show that this cooperation between international reporters and fixers has been crucial to global news reporting for a long time. Previous studies conducted in the Middle East (Murrell, 2009, 2010, 2011, 2013, 2015; Palmer \& Fontan, 2007), locally in Palestine (Bishara, 2006), Kosovo (Andresen, 2008, 2009, 2015; Paterson, Andresen, \& Hoxha, 2012), and in Pakistan (Khan, 2011, 2016, 2019) pinpoint how, on an international scale, the highly unrecognized influence of the local fixers on news reporting from the field matters. A major reason why fixers are crucial is to avoid what can be framed as 'parachute journalism,' which is itself a rather loaded term used to describe journalism where international reporters spend a short time in a conflict area, working in situ for a few days, before moving on to the next conflict:

In their efforts to gather information quickly, parachute journalists are in danger of missing facts, aspects of culture and nuances in their stories (Lundstrom, 2001; Hamilton, 2004). The parachute journalist necessarily depends on local assistance, normally in the form of a temporarily hired local person with some knowledge of journalism, an ability to translate, and good local contacts. Palmer and Fontan (2007) define fixers as an additional relay point in the process of mediated communication. Globally, fixers have impacted the content and form of international news correspondents' work more than the public has been aware of. (Hoxha \& Andresen, 2019, p. 1735)

Drawing on the realization of the importance of fixers, a pressing question emerges of why this practice was mostly ignored in journalism studies for a long time. We suggest that a reason might lie in a traditional western view of journalism, that the western practice of the profession has dominated the international news scene and input from fixers might be viewed as practical as best, and not so much in terms of producing content 
itself. However, journalism research is more diverse today. Mark Deuze (2005) points in his well-known article "What is journalism?" to the critical perspectives on journalism, e.g., especially Schudson (2001), who questions the traditional values of objectivity and detachment as absolutes. In fact, Deuze (2005) dismisses these perceived western ideal-typical values as obsolete in a modern global world and claims that it is hard to keep to them in a global and more fluid news age. According to Deuze (2005), these traditional, mostly western values, gain different meaning in different circumstances and are more a matter of journalists' self-representation than anything else. Therefore, we need to study how journalism is practiced in order to investigate this matter and to see changes in the perception of journalism to analyze how journalism is produced in extremely difficult circumstances. There is value in Deuze's (2005, p. 458) arguments that the best way to uncover the journalists work is by studying them in their daily work:

The analyses of the ideal-typical values of journalism, and how these vary and get meaning in different circumstances, have shown that any definition of journalism as a profession working truthfully, operating as a watchdog for the good of society as a whole and enabling citizens to be self-governing is not only naïve, but also one-dimensional and sometimes nostalgic for perhaps the wrong reasons. It is by studying how journalists from all walks of their professional life negotiate the core values that one can see the occupational ideology of journalism at work.

Thus, this current study of fixers in Pakistan is also a contribution to a deeper understanding of journalistic professionalism in a difficult area. The study uncovers threats and practice of journalism that is different from realities in the west. A classical western concept of journalistic professionalism is linked together with values such as 'freedom,' 'objectivity,' and 'independence' (cf. Easterman, 2000; Kumar, 2006; Price, Noll, \& de Luce, 2002; Wahl-Jorgensen \& Hanitzsch, 2009). However, in recent times, a growing body of journalism research has challenged the classical western domination of defining professional journalism. Where does this discussion stand? Beate Josephi (2007, p. 300) discusses imperatives and impediments of a possible professional model that can be internationalized, arguing that "the impediments are that no models exist to date which could be implemented around the world." Although she refers to Splichal and Sparks' (1994) research showing that journalism students worldwide have a desire for independence and autonomy, this is a long way from a single journalism model. Additionally, Curran and Park emphasize that values in journalism vary from autonomy and independence to journalists as a tool for politics (Josephi, 2007). Furthermore, Barbie Zelizer (2004, p. 576) points out that:
Research outside the Anglo-American orbit, which has so far shaped the dominant journalistic concepts, is now challenging these paradigms.... What has long been hailed as the 'professional model' centering on the ideal of the objective reporter, is now seen as just that: a model upheld but rarely attained. The question therefore is, why should a model stay a model of it so far removed from what is actually practised in newsrooms around the world?

The value of objectivity as a central part of a model has been criticized (Schudson, 2001, 2003), as well as value-neutrality (Deuze, 2005). The European discussion on journalism raises journalists' preferred values and ideas over objectivity norms (Donsbach \& Klett, 1993). De Burgh (2005, p. 2) emphasizes "that the old fallacy that all journalisms were at different stages on the route to an ideal model, probably Anglophone, is passé." Furthermore, Stephen Reese (2001) problematizes attempts to create an international standard of journalistic professionalism. He argues that the growing urge to do so stems from the fact that journalism is a growing academic field and an increasing number of scholars have received formal training in journalism. There is, therefore, a growth of transnational, comparative studies attempting to find a global view on journalism: "This transnational view of the profession has found the social survey a natural methodological approach, allowing scholars to make general descriptive statements about the nature of these journalists and their adherence to certain professional tenets" (Reese, 2001, p. 174).

In the case of fixers in Pakistan, a challenging question arises of how a 'non-western' Pakistani fixer helps to raise professionalism in western reporters' work. Furthermore, how does local knowledge merged with international experience produce credible journalism? To investigate this, we need to understand the challenging context for this news production, in addition to changes in the profession.

\subsection{Pakistan as a Journalistic Hot Spot}

The roles of fixers in international journalism are changing. As the nature of conflicts has changed, so have the dynamics of the reporting from war or conflict zones. Moreover, the role of the fixer has evolved from translators to investigators, mediators, and embedded journalist. Fixers have become increasingly professionalized through cooperation with foreign reporters (Hoxha \& Andresen, 2019). After the US invasion of Afghanistan, Pakistan became a frontline state against the war on terror, providing logistical support to the International Security Assistance Force and NATO. The US invasion triggered a doctrinal shift in Pakistan's regional policies, leading to the Pak-Afghan bordering areas becoming the site of attraction for European and American media (Baerthlein, 2006). However, due to the sensitivity of the area, journalists face increasing restrictions (Khan, 2019). 
Furthermore, the low-level separatist insurgency of Balochistan in the southwestern part of Pakistan has sparked much media attention from the West, especially after the launch of the China-Pakistan Economic Corridor (CPEC), a flagship of 52 different megaprojects under construction in Pakistan. The multibillion-dollar infrastructure and energy investments include energy projects, construction of power plants, and the development of road and railway network for establishing a corridor from the northern Chinese province of Xinxiang to Gwadar in Pakistan's restive Balochistan province. The corridor will connect Gwadar to northern China for trade purposes, but the most important element is the construction of the communication infrastructure in Pakistan (Ibrar, Mi, Rafiq, \& Karn, 2016, pp. 434-439). CPEC has received much criticism from the West and fierce resistance from ethno-Baloch nationalists after its launch Chinese workforce had come under attack several times (Hameed, 2018), also reported in the strategic port city of Gwadar in May 2019 (BBC, 2019). In order to avoid media attention to growing anger, Pakistani authorities restricted western media workers from accessing this region.

Moreover, the security situation for media workers in this region has deteriorated alarmingly in recent years. The Committee to Protect Journalists (2018) noted: "The military has quietly, but effectively, set restrictions on reporting: from barring access to regions including Balochistan where there are armed separatism and religious extremism, to encouraging self-censorship through direct and indirect methods of intimidation, including calling editors to complain about coverage and even allegedly instigating violence against reporters".

\subsection{Roles and Risks for Fixers}

From regimes to militant groups and Islamist hardliners, there is a tremendous pressure on fixers. Additionally, they are rarely supported when they find themselves in trouble for the work they do for international media outlets in conflict zones. In foreign correspondence particularly, fixers play an important role "on the ground," arranging interviews that otherwise could not be undertaken by the foreign correspondent due to lack of access and lack of knowledge of the local environment (Yong \& Rrahmani, 2018).

With the passage of time, the role of the fixer has also widened on account of the more complex nature of journalism in the conflict zones. For example, in Pakistan, a fixer also pitches story ideas to foreign correspondents; therefore, some of them self-identify as producers or fulltime journalists. Researchers have focused on the varied tasks and role of fixers as they complete in different parts of the world and the dangers they encounter in the field (Armoudian, 2016; Cottle, Sambrook, \& Mosdell, 2016; Hannerz, 2004; Paterson et al., 2012; Tumber \& Webster, 2006). For example, fixers interpret elements of nonverbal communication, serve as cultural translators and news gatherers, assist the out-front reporters, book hotels and arrange transportation, find interview subjects, secure access to government officials, and cover dangerous locations (Hoxha \& Andresen, 2019; Murrell, 2019; Plaut \& Klein, 2019). Foreign correspondents don't just rely on fixers to facilitate the story, but it is often the fixer that unearths and reports the story (Murrell, 2010; Paterson et al., 2012).

While some of these media workers take pride in their role in fixing tough challenges, others dislike the term 'fixer' because of its association with unskilled workers, whereas others prefer being called journalistfixer (Palmer, 2019, p. 3; Plaut \& Klein, 2019). In Pakistan, some fixers dislike being called fixers and identify themselves as fulltime journalists. The job of a fixer differs from area to area in Pakistan. In larger cities like Islamabad, Lahore, and Karachi they work as translators; however, in the conflict zones, they also secure interviews with notorious militant leaders. In most of the cases, fixers are not credited, but they are typically wellpaid compared to local income standards (Murrell, 2010; Paterson et al., 2012).

Mostly, fixers are approached by foreign correspondents on sensitive matters in Pakistan. Fixers interviewed for this study claimed that some foreign journalists perceive the local fixers as mere instruments to attain their objectives and then drop them without further thought. It is more like a post-colonial approach, outlined by Plaut and Klein (2019, p. 1700): “Post (anti) colonial approaches offer tools to better understand the ongoing process of maintaining global hierarchies within the practice, and production, of global journalism."

\section{Methodological Approach: In-Depth Interviews}

The findings of this study are based on qualitative indepth interviews which were conducted between March and April 2019. We adopted purposive sampling techniques, engaging with prominent journalists and fixers in Pakistan, to identify foreign correspondents and fixers who report or had reported for the international media in the Balochistan and KPK provinces. Locating the fixers proved arduous, as most do not make themselves available for interviews out of the fear of the treatment meted out to them as a payback for their reporting in the field. The interviews with fixers were conducted via an end to end encrypted application WhatsApp using the corresponding author's personal contacts in Pakistan. The security challenges and the treatment they receive from the authorities and militants has been crucial focus of this study. Foreign correspondents largely rely on fixers from these areas because, as stated in the introduction, they are rarely issued a NOC, a fundamental requirement to visit Balochistan.

In line with the main research questions, we developed a semi-structured interview guide where we asked the following questions to the fixers: (a) What was your first experience working as a fixer?; (b) What help do you 
get from your foreign colleague when you encounter a serious security problem?; (c) What are the specifics of being a fixer in Pakistan? Correspondingly, we asked the foreign correspondents to answer the following: (I) How do you or your organization help fixers when they encounter any challenge?; (II) What effects do fixers have on your work?; (III) What key challenges do fixers face in Pakistan's militancy-ridden areas like Balochistan and KPK? The answers to these questions were included in the research design to consider key components of the main research questions of this study related to challenges and risks they face while reporting from these two provinces.

Interviews were conducted in Urdu and English languages separately. The Urdu interviews were later translated and verified by the authors. Upon on the request of two fixers, transcriptions of their responses were shared with them. The identities of our respondents are kept anonymous due to security concerns.

\section{Findings: Increasing Risks and Decreasing Help}

Through qualitative interview analysis of the data from the interviews, we have identified 6 main findings presented in the sub-sections below.

\subsection{The Risks Are Increasing for Fixers in Pakistan's Militancy-Ridden Areas}

In recent years, Pakistani fixers have experienced increasing risk in performing their tasks, feeling trapped between state and non-state actors. Respondents interviewed say they are persecuted and fear for their security in chasing stories for the western media. Based on the interviews for this project, it could be concluded that working in an environment without minimum security and an absence of law and order means exposing yourself to risk. The security situation in Pakistan's northwestern KPK region, which once was the hub of Taliban activities, and like the current situation in Yemen and Syria. While working, fixers explain that during work they typically face intimidation and endure threats and abuse, all intended to reduce the impact of their work and ultimately to silence them completely. The fixers say they often face significant discontent and hopelessness when reporting on a story which involves the government and armed groups. One of our interviewees explained that "only because of your journalistic works in this region you could easily be whisked away, targeted or killed. Unfortunately, in most of the cases, the killers enjoy impunity" (Personal interview with a fixer).

Both fixers and foreign journalists say that when reporting from areas where militants operate openly, with reference to the porous border with Afghanistan and Iran, there are increasing security risks and this is a reason they never receive permission to visit such areas. One foreign correspondent, who covered Balochistan and KPK provinces, explained:
The authorities never like the ones who without its permission trespass into Balochistan and tribal region in the north which is clandestinely declared as a nogo area for the international media. The law enforcement agencies and insurgent groups have committed massive human rights violations in these regions, especially in Balochistan. In these areas, people accuse the military of enforced disappearances and killing political activists. This is a reason why authorities restrict foreign journalists from entering Balochistan. In the north, there are militant groups being sheltered by the Pakistani government that it uses as a proxy against Afghanistan and India. (Personal interview with a foreign correspondent)

Western Journalists say they face harassment while visiting Balochistan, shown in the way of creating legal hurdles, for example requiring a NOC, which is hard to get. Many of our respondents say that working on assignments relating to militancy, terrorisms, and security issues in southwestern and northwestern provinces means exposing yourself to greater security risk, heightened when working among locals. One of the major irritations of local fixers, particularly in northern Pakistan, is that most of their journalistic achievements are overshadowed by the foreign correspondents who hire them for this arduous work.

\subsection{Pakistani Military Threatens Fixers}

From the data collected through interviews it is evident that fixers and foreign correspondents face serious threats to their personal security when reporting from Balochistan and KPK provinces. While threats come from the Islamist militants, Pakistani military, and intelligence agencies, a local fixer interviewed from Quetta, the provincial capital of Balochistan, says that the least acknowledged threats they face in the province are that of the military, particularly the Inter-Service Intelligence (ISI), the country's powerful spy agency. Sharing his first experience while working with a foreign journalist he said he was placed under strict surveillance for more than two years only because he worked with a foreign correspondent in Quetta on stories that involved central government and Islamist and Baloch insurgents:

I know that the authorities don't permit foreign correspondents to visit and report from Balochistan. In rare cases when they allow them, they are followed by at least personnel from three to four security agencies. They demand details of the interviewees sometimes personal information of the respondents. Under such circumstances, no foreigners like visiting Balochistan but they rely on us [fixers]. When I was a fixer for a foreign journalist for the first time, I became suspicious. The intelligence agencies started following me. I visited them [agents of intelligence agencies] every day to prove that I am not serving a foreign agenda. It took 
me two years to prove that. (Personal interview with a Quetta-based fixer)

In Balochistan, ISI responds severely to journalists who are critical of the central government's policies. This sentiment is echoed by the foreign correspondents we interviewed, who indicated that the risks of arbitrary detainment, detention, or imprisonment increase significantly when reporting from Balochistan. The province has been the epicentre for sectarian outlets and Taliban armed groups since the US intervention in Afghanistan in 2003, when it is believed that the leaders of the Afghan insurgent movement then moved to Pakistan, specifically in the western district of Quetta. The province is also a hub of separatist activities and lethal counterinsurgencies. Western journalists indicated that this was one of the reasons why the powerful military establishment seeks to prevent foreign journalistic activity in the province. This opinion was purportedly affirmed when two Indian journalists were expelled from the country in 2014 for reporting news stories about Balochistan (Boone \& Baloch, 2016). For western correspondents, Balochistan still remains a no-go area. A western journalist said: "Balochistan remains a no-go area for foreign journalists. In case a foreign correspondent enters the province without informing the authorities, he or she might be expelled from the country" (Personal interview with a foreign correspondent).

\subsection{There Are Frequent Physical Assaults on Fixers}

Attacks on the journalist fraternity have become a norm in Pakistan, which is reflected by Pakistan's World Press Freedom Index ranking which Reporters Without Borders (RSF) publish annually. The country ranks 142nd out of 180 countries (RSF, 2019), recognizing Pakistan as one of the toughest and most dangerous areas for journalists in the world. Our interviewees agree with this ranking. According to Amnesty International (2014), journalists in Balochistan face even greater harassment, and this at the hands of political parties and intelligence agencies. These threats are considered much more severe than those of the various militant organizations.

The western journalists interviewed agree that working as a fixer for a foreign media outlet can make you an easy target in this remote, tribal, and impoverished region of Pakistan. A foreign correspondent told us that one of his fixers was kidnapped by law enforcement agencies from northern Pakistan in 2014 and suffered serious mistreatment. This happened as a reaction to the US drone strikes in North and South Waziristan regions. When we asked the fixer about the consequences he suffered after helping the foreign reporter, the experiences he shared were heartbreaking:

I was kidnapped for documenting sensitive issues like Taliban brutalities, and I was in illegal detention by law enforcement agencies. I know that this was because of civilian casualties caused by US drone strikes. I was picked up by secret agencies several times. I was tortured, handcuffed, and faced threats from the Taliban for years and in the end, my own media organization abandoned me. (Personal interview with former fixer)

Nevertheless, fixers in Balochistan and KPK play a significant role in providing access to international correspondents in these remote, but volatile regions. With reference to the theoretical discussion earlier in this article about journalistic professionalism that grows out of the cooperation between local fixers and international reporters, we observe that the fixers we interviewed said they try to report in a balanced way about the suffering of local people. They experience militancy, terrorism, religious extremism, and political upheavals in their daily life, while in return they are threatened, kidnapped, tortured, and left unprotected by the media outlets they work for.

A Baloch fixer from Gwadar related how many western journalists have been coming to the port city since the launch of the CPEC and typically these leave after completion of their assignments. The fixers, however, bear the consequences of the western journalists' antiChina style of reporting:

I always push my foreign and national counterparts to try to keep a balanced approach while reporting any story from Balochistan so that we continue to bring untold stories. But they do what they like. And in return, we pay the price for that. Many of us had been tortured, threatened and forced to give up journalism only because of anti-China stories by the westerners. Even I know people who have been first accused of being foreign agents and then tortured by unknown people. Unfortunately, culprits in such cases enjoy impunity. (Personal interview with a fixer)

Journalism in Pakistan generally, and in its Balochistan and KPK provinces in particular, has become a more dangerous practice in recent years. Research undertaken by the Council of Pakistan Newspaper Editor and Freedom Network shows that 133 journalists have been killed in Pakistan since the year 2000 (Rehman, 2019; Rehmat \& Khattak, 2019). The fixers we interviewed from Balochistan claim that this number represents only the high profile cases that have been spotlighted in mainstream media. They say that there have been many other cases of torture, harassment, intimidation, and narrow assassination attempts among fixers, which are rarely reported upon.

\subsection{Islamist Threats Against Fixers and International Reporters Are on the Rise}

Foreign correspondents and local fixers say they are not only threatened by the government and political parties, but they also face continual threats of violence from religiously motivated groups such as the Taliban and 
the Islamic State of Khorasan. Sectarian outfits such as Lashkar-E-Jhangvi (The Army of Jhangvi) and other religiously motivated groups are also guilty of this. A western journalist describes Balochistan as an information "black hole" for the media due to threats posed by hardline Islamist and law enforcement agencies:

We apply for NOCs and don't receive replies for months. It is very difficult to obtain a NOC and visit Balochistan. Balochistan is sort of a black hole where there is no real possibility to visit and report as we do in other countries in this region. I have tried visiting Balochistan twice. But it is difficult, and I have been denied NOC. There are fixers who provide inputs on the ground situation. However, they feel insecure due to numerous threats and intimidations they receive every day from the government and hardline Islamists. (Personal interview with foreign correspondent)

Sharing his experiences of helping a western media outlet, a local Baloch fixer says he had been detained and interrogated by the country's intelligence services in the province for attempting to interview leaders of Quetta Shura (the notorious Quetta Shura is composed of leaders of Afghan-based Taliban believed to be based in Quetta):

When you are chasing a story in Balochistan, especially for foreign media that involves security issues, militants and government push their narrative and in many cases that seems impossible. Government officials never like it that the insurgents' narrative is being written and the insurgents never like the government narrative. If you fail to do so, any of them can label you a foreign or military agent and kill you. We are caught between insurgents and the military. (Personal interview with fixer)

Foreign correspondents in Islamabad we interviewed agree that working on a story that involves the country's security issues and Taliban activities can raise serious outrage. A foreign journalist explains:

The fact of the matter is that religious tolerance, unfortunately, has been reduced to nothing due to some state policies and overwhelmingly by the pervasive extremist elements within the society who continue to unleash terror in the name of religion without anybody keeping them in check. (Personal interview with a foreign journalist)

The Baloch fixer mentioned earlier, who tried to interview the leader of the notorious Quetta Shura, says that on one occasion he was taken away by the country's powerful intelligence directorate of the Military Intelligence in 2006, while his associate foreign colleague was physically abused for covering a political uprising against the central government in Balochistan. He says that arbi- trary detention has become part of his journalistic life. Journalists and fixers say the Pakistani state has zerotolerance for journalists trying to meet with leaders of Islamist militants and Baloch separatists. According to a foreign correspondent, other than the political and security affairs of the country, a critical challenge that remains off limits to the media is the insecurity of religious minorities in Balochistan and KPK provinces, especially Shiites Hazaras, an ethnic group that has suffered persecution at the hands of Islamic State in Afghanistan and Balochistan.

Working on a story that involves the insecurity of Shiites Hazaras can raise outrage from Islamist and religious parties. From time to time, this pressure makes journalists compromise their professional standards, leading to self-censorship. Fixers from the Balochistan and KPK provinces said that most of the time they avoid critical reporting when it involves religious-based terrorism. Hindus and Christians are ostracised by the people, and their loyalty to the country is doubted. In this tense environment, the fixers said they cannot truly help the foreign correspondents who are in search of certain news. The same fixers also realize that as soon as a story is completed, the foreign correspondents will move on, while the extremist elements within the country will not spare them and rarely, they receive any support from their foreign counterparts in case of any trouble. Several of the foreign correspondents we interviewed, however, don't agree with this claim. A former The Guardian journalist we interviewed who until recently covered Afghanistan and Pakistan explains:

When things do go wrong, The Guardian will spend time and resources trying to get journalists out of trouble. Two of my fixers were kidnapped twice in Afghanistan when I worked there and senior executives at The Guardian, including the editor, were involved in trying to get his release.

\subsection{There Are No Real Safe Zones for Fixers}

Pakistan today is deemed as one of the most feared countries for journalists due to the series of killings by state and non-state actors that have taken place in Balochistan and KPK provinces. Many of these have been fixers or little-known media workers and were not highlighted by the mainstream media or civil society. The fixers and foreign correspondents who were interviewed for this study say Pakistan's Balochistan and KPK provinces hit by violent insurgencies and Islamist militancy are the hardest places for media workers to work. Talking about lack of safety training, a Pashthun fixer explains that "in a place where there is no rule of law one can blindfold and kidnap a fixer with impunity even in a crowd, and it makes things harder to work without safety training" (Personal interview with a fixer).

A London based investigative correspondent who covers terrorism, religious militancy, and politics from 
Pakistan, says safety remains a key challenge for them. She stated that many fixers in Peshawar are selfcensoring due to direct threats to their lives. She says that when she was working on an investigation in Peshawar it was challenging to find a fixer that would be willing to work on such a contentious subject as that of Dr. Shakil Afridi (the doctor who unearthed Osama bin Laden's location). In her words, the fixers were very concerned about the security agencies, especially the powerful intelligence agencies who have been known to apply significant pressures on journalists and fixers to dissuade them when covering difficult issues and working without fixers on such subjects is challenging. She said the most challenging aspect of working in Pakistan is accessing comments from law enforcement agencies. These are the most challenging milieu due to the precarious nature of corruption, and it can be very stressful, such that only an experienced fixer can accomplish such tasks. The value of having a fixer in dangerous areas cannot be underestimated. In answering a question on what effects fixers had on foreign corresponding, she states that:

A fixer has a positive influence on our work. When covering human interest stories in remote provinces in the country it is very helpful to hire a fixer. The impact on coverage is significant and the nuance and unique insight can only be possible with the assistance of a local fixer. (interview with a foreign correspondent)

\subsection{There Is Hope in Mutual Learning Between Fixers and Journalists}

This last finding shows that there is some hope in times of despair for fixers in Pakistan. Despite facing problems and threats, fixers from Pakistan's remote but troubled areas say that they get professional growth by working with foreign correspondents in Pakistan. There is a mutual learning outcome between foreign journalists and local fixers. This suggests that the cooperation between reporters and fixers also produces positive results. Fixers we interviewed have told us that they learn various reporting techniques from their foreign peers. There is also economic gain from fixers working with their international counterparts. One fixer from northern Pakistan says:

Many of us do not know about investigative reporting, research methods, and new techniques of reporting. While working with a foreign journalist, we learn various reporting techniques. They provide resources, guidelines, money, and other tools to utilize them and gather information. Working alongside a foreign journalist, who has decades of experience covering wars and conflict, can enrich our reporting skills. (interview with a fixer)

This echoes findings in other studies about the relationship between fixers and their foreign counterparts (Hoxha \& Andresen, 2019; Yong \& Rrahmani, 2018), which state that besides earning money, fixers also gain professionalism. Our informants agreed and say by working with the international correspondents, they are becoming more professional and getting a higher income, but seldom get recognition for their challenging and risky assignments. In addition, foreign correspondents from Islamabad say in our interviews that they enjoy working with their local fixers. Thanks to this, they gain access to no-go areas and controversial militant leaders.

\section{Conclusion: Despair and Hope}

This current study shows that Pakistan is of major interest to international journalists due to western military engagement in Afghanistan. Pakistan's no-go areas for foreign media practitioners, which border Afghanistan, primarily remain a centre of coverage due to western engagement in neighbouring Afghanistan. However, as western journalists face heavy travel restrictions, they hire local fixers to achieve their goals. Although it can be ascertained that fixers, particularly in Pakistan's more troubled regions, face serious security risks from state and non-state actors, still, many say in our interviews that they wish to continue carrying out dangerous and brave work. The question remains, however, for how long this will be the case when their security isn't guaranteed.

As discussed in this article, the impact of fixers on international media coverage is significant and is rarely acknowledged. Media outlets covering the region can only access hotspots with the assistance of a local fixer. However, for many, the reward for fixers rarely outweighs the associated risks. It is due to the efforts of fixers that western media are operating from Pakistan's militancy-hit areas. Fixers rarely have insurance and there are no laws to protect them. This article revealed that fixers have been tortured and harassed, and in some extreme cases, have been killed. The fixers are placed in a dilemma for their security, because neither the international journalistic laws protect them nor the very media outlets or the correspondents who hire them in the first place provide protection for them.

On a positive note, the mutual relationship of the foreign correspondents and the fixers has evolved from exploitation to become mutually beneficial. Thus, there is a relationship forming that produces professional journalism. Still, fixers are deprived of the rights and privileges which cover the foreign correspondents. The credit or byline for such risk-laden reporting only goes to the foreign correspondent. In return, the foreign journalists pay local fixers a handsome amount of money for their reporting. Thus, the efforts a fixer makes and all the risks a fixer faces are often discarded. Finally, it is our hope that fixers will gain more credit and recognition. The fixers are, perhaps surprisingly, often equally professional in the tasks, as they maneuver in difficult terrain in Pakistan. Due to this, they must be given more protection and considered as valuable in international reporting in risky areas. 


\section{Acknowledgments}

The authors want to thank the local fixers and international reporters who have contributed with crucial information for this article. They work and live in challenging circumstances, and we appreciate their time and knowledge they have shared with us. We also want to thank the University of Agder and NLA University College for continual support.

\section{Conflict of Interests}

The authors declare no conflict of interests.

\section{References}

Amnesty International. (2014). Pakistan: "A bullet has been chosen for you": Attacks on journalists in Pakistan. London: Amnesty International. Retrieved from https://www.amnesty.org/en/documents/ ASA33/005/2014/en

Andresen, K. (2008). Fikseren: Mer enn journalistens usynlige hjelper? ['The fixer': More than the journalists' invincible helper?] Norsk Medietidsskrift, 15(2), 146-149.

Andresen, K. (2009). Producing 'protocol news' in Kosovo's public broadcaster: Journalism in a transitional risk society. Conflict and Communication Online, 8(2), 1-16.

Andresen, K. (2015). Journalism under pressure (Unpublished Doctoral dissertation). University of Oslo, Oslo, Norway.

Armoudian, M. (2016). Reporting from the danger zone: Frontline journalists, their jobs, and an increasingly perilous future. New York, NY: Routledge.

Aslam, R. (2015). Media, politics and the threats to journalists in Pakistan. Pacific Journalism Review, 21(1), 177-194.

Baerthlein, T. (2006). Too little research, too many clichés. Qantara.de. Retrieved from https://en. qantara.de/content/the-image-of-pakistan-inwestern-media-too-little-research-too-many-cliches

BBC. (2019). Pakistan attack: Gunmen storm five-star hotel in Balochistan. BBC. Retrieved from https://www. bbc.com/news/world-asia-48238759

Beck, E., \& Delmenico, D. (2017). Fixers taking all the risks but reaping the little reward. City Journal. Retrieved from http://thecityjournal.net/reportingfrom-pakistan/fixers-taking-all-the-risks-butreaping-little-reward

Bishara, A. (2006). Local hands, international news: Palestinian journalists and the international media. Ethnography, 7(1), 19-46.

Boone, J., \& Baloch, K. (2016). Balochistan: Pakistan's information blackhole. The Guardian. Retrieved from https://www.theguardian.com/world/2016/feb/04/ balochistan-pakistan-information-black-hole

Cottle, S., Sambrook, R., \& Mosdell, N. (2016). Reporting dangerously: Journalist killings, intimidation and security. Basingstoke: Palgrave Macmillan.

de Burgh, H. (Ed.). (2005). Making journalists. New York, NY: Routledge.

Deuze, M. (2005). What is journalism? Professional identity and ideology of journalists reconsidered. Journalism, 6(4), 442-464.

Donsbach, W., \& Klett, W. (1993). Subjective objectivity: How journalists in four countries define a key term of their profession. Gazette, 5(1), 53-83.

Easterman, M. (2000). One-legged media, lame democracy: Experiences from Albania and Bosnia. International Journal of Cultural Studies, 3(2), 240-256.

Hameed, M. (2018). The politics of the China-Pakistan economic corridor. Palgrave Communications, 4(1), 1-10. https://doi.org/10.1057/s41599-018-0115-7

Hannerz, U. (2004). Foreign news: Exploring the world of foreign correspondents. Chicago, IL: University of Chicago.

Hoxha, A., \& Andresen, K. (2019). The development of roles in Kosovo: From fixers to journalists. Journalism Studies, 20(12), 1732-1746. https://doi.org/10. 1080/1461670X.2019.1639539

Ibrar, M., Mi, J., Rafiq, M., \& Karn, A. L. (2016). The ChinaPakistan economic corridor: Security challenges. Paper presented at the 2nd Asia-Pacific Management and Engineering Conference, Shanghai, China.

Josephi, B. U. (2007). Internationalizing the journalistic professional model: Imperatives and impediments. Global Media and Communication, 3(3), 300-306.

Khan, A. (2011). Reporting the frontier: Media and its capacity building for peace in Pakistan's tribal areas bordering Afghanistan. Saarbrücken: VDM Verlag Dr. Müller.

Khan, A. (2016). The human face of FATA: Role of media in the building of FATA's image. In A. Soharwordi (Ed.), Socio-economic and political currents in FATA: $A$ way forward (pp. 45-59). Peshawar: The University of Peshawar.

Khan, A. (2019). Fixers in corporate media: Pashtun journalists under threat in North-Western Pakistan. Conflict and Communication Online, 18(1), 1-9. Retrieved from https://doaj.org/article/ 4c1a9549a17f41c9a410765b9271ef14

Kumar, K. (2006). Promoting independent media: Strategies for democracy assistance. Boulder, CO: Lynne Rienner.

Murrell, C. (2009). Fixers and foreign correspondents: News production and autonomy. Australian Journalism Review, 31(1), 5-17.

Murrell, C. (2010). Baghdad bureau: An exploration of the interconnected world of fixers and correspondents at the BBC and CNN. Media, War \& Conflict, 3(2), 125-137.

Murrell, C. (2011). Correspondents and fixers: An investigation of teamwork in international television newsgathering (Unpublished Doctoral dissertation). University of Melbourne, Melbourne, Australia. 
Murrell, C. (2013). International fixers: Cultural interpreters or 'people like us'? Ethical Space: The International Journal of Communications Ethics, 10(2/3), 72-79.

Murrell, C. (2015). Foreign correspondents and international newsgathering: The role of fixers. New York, NY: Routledge.

Murrell, C. (2019). Fixers as entrepreneurs. Journalism Studies, 20(12), 1679-1695. https://doi.org/10. 1080/1461670X.2019.1636705

Palmer, L. (2019). The fixers: Local news workers and the underground labor of international reporting. London: Oxford University Press.

Paterson, C., Andresen, K., \& Hoxha, A. (2012). The manufacture of an international news event: The day Kosovo was born. Journalism, 13(1), 103-120.

Plaut, S., \& Klein, P. (2019). "Fixing the journalistfixer relationship": A critical look towards developing best practices in global reporting. Journalism Studies, 20(12), 1696-1713. https://doi.org/10.1080/ 1461670X.2019.1638292

Price, M. (2002). Mapping media assistance. Oxford: University of Oxford. Retrieved from http://repository. upenn.edu/asc_papers/62

Reese, S. D. (2001). Understanding the global journalist: A hierarchy-of-influences approach. Journalism Studies, 2(2), 173-187.
Rehman, I. A. (2019). Media's shrinking space. Dawn. Retrieved from https://www.dawn.com/news/ 1518002/medias-shrinking-space

Rehmat, A., \& Khattak, I. (2019). Crime and punishment in Pakistan's journalism world. Islamabad: Freedom Network.

RSF. (2019). Under the military establishment's thumb. RSF. Retrieved from https://rsf.org/en/pakistan

Schudson, M. (2001). The objectivity norm in American journalism. Journalism, 2(2), 149-170.

Schudson, M. (2003). The sociology of news. New York, NY: W. W. Norton.

Splichal, S., \& Sparks, C. (1994). Journalists for the 21st century. Norwood, NJ: Ablex.

Tumber, H., \& Webster, F. (2006). Journalist under fire: Information war and journalistic practices. Thousand Oaks, CA: Sage.

Wahl-Jorgensen, K., \& Hanitzsch, T. (Eds.). (2009). The handbook of journalism studies. New York, NY: Routledge.

Yong, W., \& Rrahmani, H. (2018). Fixers: The unsung heroes of journalism. Al Jazeera. Retrieved from https://www.aljazeera.com/programmes/listening post/2015/03/fixers-unsung-heroes-journalism150307111219380.html

Zelizer, B. (2004). Taking journalism seriously: News and the academy. London: Sage.

\section{About the Authors}

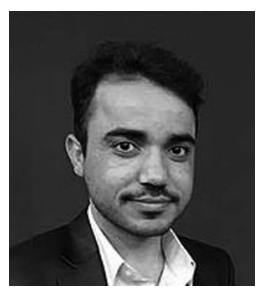

Kiyya Baloch is a Freelance Pakistani Journalist currently based in Norway. He has previously reported from Islamabad for The Guardian, Al Jazeera online and Radio Free Europe/Radio Liberty. He has reported on security and politics primarily focusing on his native Balochistan province. He often contributes to Al Jazeera and Norwegian Press in Norway. He can be found on Twitter @KiyyaBaloch.

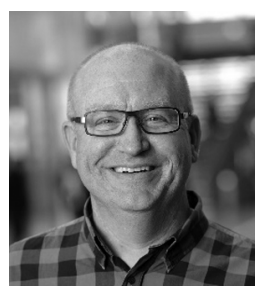

Kenneth Andresen (PhD) is Professor of Media Studies at University of Agder and NLA University College in Kristiansand, Norway, where he teaches Communication Studies and Journalism. He has published several articles and book chapters on news production and journalism in conflict areas, especially in Kosovo and the Balkans. Currently he is involved in two major research projects-RePAST (www.repast.eu) and The Worlds of Journalism Study (www.worldsofjournalism.org). He can be found on Twitter @kennethandresen. 